\title{
Faktor-Faktor yang Berhubungan dengan Kesediaan Menjadi Akseptor KB Pasca Persalinan di RSUD Deli Serdang Lubuk Pakam Tahun 2019
}

\author{
Julina Br. Sembiring1, Suyanti Suwardi ${ }^{2}$, Herna Juliati Saragih ${ }^{3}$ \\ ${ }_{1,2,3}$ Institut Kesehatan Helvetia, Medan, Indonesia \\ Correspondence email: julinasembiring@helvetia.ac.id
}

\begin{abstract}
Abstrak. Peningkatan jumlah penduduk merupakan salahsatu masalah besar bagi negara berkembang.Indonesia merupakan negara denganjumlah penduduk terbesar setelah China, India, dan Amerika Serikat. Untuk mendapatkan layanan kesehatan reproduksi yang berkualitas maka setiap pasangan usia subur harus memiliki akses yang sama terhadap alat kontrasepsi dan layanan yang dapat menyelamatkan jiwanya, salah satunya adalah program KB pasca persalinan. Bersedia menjadi akseptor KB pasca persalinan adalah merupakan pilihan bagi setiap pasangan usia subur. Tujuan penelitian ini adalah untuk mengetahui faktorfaktor yang berhubungan dengan kesediaan menjadi akseptor KB pasca persalinan di RSUD Deli Serdang Lubuk Pakam tahun 2019. Jenis penelitian ini adalah cross-sectional analitik yaitu melakukan pengukuran atau pengamatan pada seluruh variabel dependent (kesediaan menjadi akseptor KB Pasca persalinan) dengan variabel independent (pengetahuan, sikap, dukungan suami dan peran petugas). Hasil penelitian berdasarkan tabulasi silang uji chi square diperoleh kesimpulan bahwa tingkat pengetahuan ( $p$ value $0,028<0,05)$, sikap (nilai $p$ value $0,01<0,05)$, dukungan suami ( $p$ value $0,00<0,05)$, dan peran petugas kesehatan $(p$ value $0,00<0,05)$. adalah berhubungan dengan kesediaan menjadi akseptor $\mathrm{KB}$ pasca persalinan sedangkan pendidikan bukan merupakan faktor kesediaan menjadi akseptor KB pasca persalinan (nilai $p$ value $0,327>0,05$ ).
\end{abstract}

Kata Kunci: KB pasca persalinan; pengetahuan; sikap; dukungan suami; peran petugas kesehatan

Abstract. Increasing the population is one of the big problems for developing countries. Indonesia is the country with the largest population after China, India and the United States. To get quality reproductive health services, each partner of childbearing age must have equal access to contraception and services that can save his life, one of which is a postpartum family planning program. Willing to become a postpartum family planning acceptor is an option for every couple of childbearing age. Many factors are related to the willingness to become postpartum family planning acceptors. Method this research is analytical crosssectional, which is measuring or observing all dependent variables (willingness to become post-birth control acceptors) with independent variables (knowledge, attitude, husband support and officer role). The result level of knowledge ( $p$ value 0,028 $<0,05$ ), attitude (value $p$ value $0.01<0.05$ ), husband's support ( $p$ value $0.00<0.05$ ), and the role of health workers ( $p$ value 0.00 $<0.05$ ). is related to willingness to become a postpartum acceptor while education is not a willingness factor to become a postpartum family planning acceptor ( $p$ value $0.327>0.05$ ).

Keywords: postpartum family planning; knowledge; attitude; husband's support; the role of health workers

\section{PENDAHULUAN}

Bersedia menjadi akseptor KB adalah merupakan pilihan bagi setiap pasangan usia subur. Untuk mendapatkan layanan kesehatan reproduksi yang berkualitas maka setiap pasangan usia subur harus memiliki akses yang sama terhadap alat kontrasepsi dan layanan yang dapat menyelamatkan jiwanya. Salah satu layanan kesehatan reproduksi dalam hal ini adalah layanan KB. 'RSUD Deli Serdang Lubuk Pakam telah mempunyai program Pelayanan Keluarga Berencana Rumah Sakit (PKBRS), yang bertujuan untuk meningkatkan pelayanan KB di rumah sakit. Sebagai salah satu program khusus rumah sakit, PKBRS mendukung kegiatannya dengan mengadakan program $\mathrm{KB}$ pasca salin dan pasca keguguran (PP dan $\mathrm{PK}$ ).

Pembangunan kesehatan adalah merupakan suatu bagian daripembangunan nasional yang bertujuan meningkatkan kesadaran, kemauan dankemampuan hidup sehat bagi setiap orang agar terwujud derajat kesehatanmasyarakat yang setinggi-tingginya. Pembangunan kesehatan tersebut merupakanupaya seluruh potensi bangsa Indonesia, baik masyarakat, swasta maupunpemerintah (Kementerian Kesehatan RI, 2017). Peningkatan jumlah penduduk merupakan salahsatu masalah besar bagi negara berkembang. Indonesia merupakan negara denganjumlah penduduk terbesar setelah China, India, dan Amerika Serikat. Berdasarkansensus penduduk tahun 2010 diketahui jumlah penduduk Indonesia adalahsebanyak 237.641.326 jiwa, yang mencakup mereka yang tinggal di daerahperkotaan sebanyak 118.320.256 jiwa $(49,79 \%)$ dan di daerah pedesaan sebanyak119.321.070 jiwa $(50,21 \%)$ (Berlinda Wakerkwa, n.d.).

Berdasarkan survey pendahuluan di Rumah Sakit Umum Daerah Deli Serdang, yang merupakan Pusat Pelayanan Kesehatan Tipe B Terkareditasi setelah dilaksanakan PKBRS, jumlah ibu yang bersalin di tahun 2015 adalah 560 orang, di tahun 2016 yakni 620 orang dan di tahun 2017 meningkat menjadi 736 orang. Sedangkan jumlah pemasangan KB Pasca persalinan (IUD dan Implant) yang dilakukan di tahun 2015 sebanyak 81 orang, di tahun 2016 sebanyak 128 orang 
Julina Br. Sembiring et al, Faktor-Faktor yang Berhubungan dengan Kesediaan Menjadi Akseptor KB Pasca Persalinan di RSUD Deli Serdang Lubuk Pakam Tahun 2019

dan di tahun 2017 sebanyak 168 orang (Bappenas, 2013).

Hasil wawancara penulis terhadap 10 orang ibu pasca persalinan di RSUD Deli Serdang Lubuk Pakam, maka diperoleh 8 orang ibu tidak bersedia untuk menjadi akseptor KB Pasca Persalinan (IUD dan Implan) dengan alasan merasa takut dan tidak diizinkan oleh suaminya. Sedangkan ibu yang bersedia untuk menjadi akseptor KB Pasca Persalinan berjumlah 2 orang dengan alasan ingin menunda kehamilan dalam jangka waktu yang panjang.

Menurut World Health Organization (WHO) 2016 penggunaan kontrasepsi telah meningkat di banyak bagian dunia, terutama di Asia dan Amerika Latin dan terendah di Sub-Sahara Afrika. Secara global, pengguna kontrasepsi modern telah meningkat tidak signifikan dari 54\% pada tahun 1990 menjadi 57,4\% pada tahun 2014. Secara regional, proporsi pasangan usia subur 15-49 tahun melaporkan penggunaan metode kontrasepsi modern telah meningkat minimal 6 tahun terakhir. Di Afrika dari 23,6\% menjadi 27,6\%, di Asia telah meningkat dari $60,9 \%$ menjadi $61,6 \%$, sedangkan Amerika latin dan Karibia naik sedikit dari $66,7 \%$ menjadi 67,0\%. Diperkiraan 225 juta perempuan di negara-negara berkembang ingin menunda atau menghentikan kesuburan tapi tidak menggunakan metode kontrasepsi apapun dengan alasan sebagai berikut: terbatas pilihan metode kontrasepsi dan pengalaman efek samping. Kebutuhan yang belum terpenuhi untuk kontrasepsi masih terlalu tinggi. Ketidakadilan didorong oleh pertumbuhan populasi (WHO, 2016).

Indonesia merupakan sebuah negara berkembang dengan jumlah penduduk sebanyak 252.124.458 jiwa dengan luas wilayah 1.913.378,68 km2 dan kepadatan penduduk sebesar $131,76 \mathrm{jiwa} / \mathrm{km} 2$ (1). Masalah yang terdapat di Indonesia adalah laju pertumbuhan penduduk yang relatif masih tinggi. Perkiraan penduduk pertengahan (2013) sebesar 248,8 juta jiwa dengan laju pertumbuhan penduduk sebesar $1,48 \%$. Laju pertumbuhan ditentukan oleh kelahiran dan kematian dengan adanya perbaikan pelayanan kesehatan menyebabkan tingkat kematian rendah, sedangkan tingkat kelahiran tetap tinggi hal ini penyebab utama ledakan penduduk. Menekan jumlah penduduk dengan menggalakan program Keluarga Berencana (KB) (Kementerian Kesehatan RI, 2017).

Proporsi penggunaan KB di Indonesia berdasarkan hasil Riskesdas tahun 2017 adalah 55,8\% menurut hasil Survei Demografi dan Kesehatan Indonesia (SDKI) 2013 yaitu $57,9 \%$ serta $59,7 \%$ pada hasil Riskesdas 2017. Penggunaan KB di Indonesia berdasarkan hasil SDKI tahun 2017 didominasi oleh penggunaan KB jenis suntik (32\%) dan pil (14\%). Kontrasepsi suntik dan pil memerlukan kontrol bulanan untuk melakukan suntik ulang maupun untuk memperoleh pil KB Diharuskannya kontrol untuk mendapatkan pelayanan kontrasepsi ulang mengakibatkan angka putus pakai pada metode tersebut cukup tinggi dibandingkan dengan alat kontrasepsi yang tergolong metode kontrasepsi jangka panjang. Hasil SDKI 2017 menunjukkan bahwa angka putus pakai KB tertinggi yaitu pada pengguna kontrasepsi pil (40.7\%) yang diikuti oleh kontrasepsi jenis suntik (24.7\%) (Kementerian Kesehatan RI, 2017).

Di Sumatera Utara peserta KB AKBK secara nasional 50,18\%. Data dari BKKBN Provinsi Sumatera Utara tahun 2017 menunjukkan cakupan penggunaan alat kontrasepsi IMPLANT $(7,1 \%)$, IUD $(7,2 \%)$, MOP $(0,4 \%)$, MOW (4,9\%), SUNTIK $(22,2 \%)$, PIL $(21,1 \%)$, KONDOM (5\%). Data tersebut tidak sesuai dengan target nasional dari AKBK yakni 60\% (Kementerian Kesehatan RI, 2017).

Sumatera Utara merupakan provinsi keempat yang terbesar jumlah penduduknya di Indonesia setelah Jawa Timur, Jawa Barat dan Jawa Tengah. Berdasarkan data dari BPS Provinsi Sumatera Utara, jumlah penduduk Sumatera Utara tahun 2014 tercatat sebesar 13.326.307 jiwa, meningkat dari tahun 2013 sebanyak 110.906 jiwa (0,84\%) dari 13.215.401 jiwa. Jumlah Pasangan Usia Subur (PUS) di Provinsi Sumatera Utara tahun 2013 yaitu sebesar 2.184.486 orang dengan jumlah peserta KB baru sebanyak 424.583 orang $(19,44 \%)$ dan jumlah peserta KB aktif sebesar 1.477 .026 orang $(67,61 \%)$. Jumlah peserta KB aktif menurut jenis kontrasepsi yang digunakan paling tinggi adalah suntik dengan jumlah 481.113 orang $(32,57 \%)$ dan disusul dengan pil sebanyak 452.150 orang $(30,61 \%)$ (Kementerian Kesehatan RI, 2017).

Jumlah PUS pada tahun 2016 di Kota Medan adalah 330.376 orang dengan jumlah peserta $\mathrm{KB}$ aktif yang menggunakan Pil sebanyak 69.404 orang $(31,40 \%)$ yang berada di urutan kedua setelah pengguna alat kontrasepsi Suntik yaitu sebanyak 77.711 orang $(35,15 \%)$, IUD 29.249 orang $(13,23 \%)$, MOW 13.414 orang $(6,07 \%)$, Implan 16.025 orang $(7,25 \%)$, dan Kondom 13.127 orang $(5,94 \%)$ (7). Sedangkan berdasarkan data BKKBN Kabupaten Deli Serdang jumlah PUS tahun 2016 di Kabupaten Deli Serdang adalah 281.200 orang (Badan Kependudukan dan Keluarga Berencana Nasional, 2013).

Pelayanan KB di Rumah Sakit sangat potensial memberikan sumbangan pencapaian target Program KB Nasional, dapat menjadi peluang sasaran pelayanan KB (menurunkan unmet need), dan menurunkan Angka Kematian Ibu (AKI). Salah satu program yang sedang digalakkan kembali adalah Program KB pasca persalinan dengan salah satu pilihan kontrasepsi adalah IUD Post Partum yaitu pemasangan IUD segera setelah melahirkan/IUD pascaplasenta (dalam 10 menit setelah plasenta lahir/IUD pascaplasenta, dalam 48 jam dan setelah 4 minggu) serta pemasangan IUD Pasca Sectio 
Julina Br. Sembiring et al, Faktor-Faktor yang Berhubungan dengan Kesediaan Menjadi Akseptor KB Pasca Persalinan di RSUD Deli Serdang Lubuk Pakam Tahun 2019

Caesarea. Program insersi IUD Post Partum merupakan progam lama namun sudah tidak lagi menjadi popular, padahal penggunaan IUD ini cukup aman dan perlu ditawarkan dengan melakukan konseling terlebih dahulu sebelum persalinan kepada ibu hamil. Adanya cara yang relative baru yaitu insersi IUD pascaplasenta yang mungkin bisa menjadi harapan dan kesempatan bagi banyak ibu yang tidak ingin hamil lagi (Tita.H.M, 2014).

Program Keluarga Berencana Pasca Persalinan dan Pasca Keguguran (KB PP dan PK) rumah sakit sangat strategis memberikan kontribusi terhadap akselerasi penurunan angka kematian ibu dan bayi baru lahir melalui pelayanan yang terjangkau dan berkualitas. Kenyataannya sebagian besar kasus persalinan dan keguguran di rumah sakit yang merupakan kasus rujukan berisiko kematian, hanya 5-10\% saja yang terhindar dari risiko kehamilan berikutnya dengan cara ber-KB. Metode kontrasepsi setelah persalinan dan keguguran umumnya dipilih berdasarkan riwayat penyakit, faktor anatomi, hormonal dan laktasi. Rumah sakit yang berperan sebagai pusat rujukan primer, sekunder dan tertier diwajibkan menyediakan pelayanan KIE dan konseling KB yang diarahkan pada terciptanya akseptor mantap (MOW/MOP) yang merupakan metode kontrasepsi yang efektif.

Secara optimal perencanaan pelayanan kontrasepsi sebaiknya dibuat sejak pelayanan antepartum, direvisi paling lambat sebelum ibu pulang dari rumah sakit dan dilaksanakan pada 3 minggu pasca salin. PKBRS cukup efektif dan efisien dalam akselerasi penurunan kematian maternal dan saat sekarang yang utama dilaksanakan adalah program KB pasca salin (KBPS) dan KB pasca gugur (KBPG). Pemilihan IUD sebagai KBPS dan KBPG merupakan pilihan kontrasepsi unggulan disamping metode KB yang lain (Tita.H.M, 2014).

\section{METODE}

Penelitian ini dilakukan dengan pendekatan kuantitatif dengan desain cross-sectional analitik yaitu melakukan pengukuran atau pengamatan pada seluruh variabel dependent (kesediaan menjadi akseptor $\mathrm{KB}$ Pasca persalinan) dengan variabel independent (umur, pendidikan, paritas, pengetahuan, sikap, dukungan suami dan peran petugas) dilakukan dalam waktu yang sama untuk mengetahui faktor-faktor yang mempengaruhi kesediaan menjadi akseptor KB Pasca persalinan di RSUD Deli Serdang Lubuk Pakam.

Data primer yang dikumpulkan melalui pengisian kuesioner berisi daftar pertanyaan yang disampaikan kepada responden untuk dijawab secara tertulis. Kuesioner untuk mengetahui faktor-faktor yang mempengaruhi kesedian menjadi akseptor KB Pasca persalinan. Data sekunder yang diperoleh dari pihak Rumah Sakit Umum Daerah Deli Serdang Lubuk Pakam. Data tertier melalui studi kepustakaan, seperti: jurnal kesehatan yang telah dipublikasikan oleh pengarang.

Menggambarkan karakteristik masing-masing variabel yang diteliti dengan menggunakan distribusi frekuensi dan presentase masing-masing variabel Independen dan Dependen.

Analisa Univariat untuk menjelaskan atau mendiskripsikan karakteristik masing-masing variabel yang diteliti secara sederhana yang disajikan dalam bentuk tabel distribusi frekuensi (RSUD Deli Serdang, n.d.).

Analisa bivariat untuk menguji hipotesis ada atau tidak ada hubungan antara variabel independen dan variabel dependen, dengan menggunakan uji statistik uji chi-square dengan derajat kemaknaan $\alpha=0,05 \%$.

\section{HASIL DAN PEMBAHASAN Analisis Univariat}

Faktor-faktor yang berhubungan dengan kesediaan menjadi akseptor KB Pasca Persalinan di Rumah Sakit Umum Daerah Deli Serdang Lubuk Pakam tahun 2018 akan dijelaskan sebagai berikut :

Tabel 1. Distribusi Frekuensi Faktor-Faktor Yang

Berhubungan Dengan Kesediaan Mmenjadi Akseptor KB Pasca Persalinan di Rumah Sakit Umum Daerah Deli Serdang Lubuk Pakam Tahun 2019

\begin{tabular}{llcc}
\hline No & \multicolumn{1}{c}{ Variabel } & f & \% \\
\hline 1. & Tingkat Pengetahuan & & \\
& Baik & 14 & 27,5 \\
& Cukup & 29 & 56,9 \\
& Kurang & 8 & 15,7 \\
2. & Sikap & & \\
& Negatif & 28 & 60,9 \\
& Positif & 18 & 39,1 \\
3. Dukungan Suami & & \\
& Mendukung & 30 & 58,8 \\
& Tidak Mendukung & 21 & 41,2 \\
4. Peran Petugas Kesehatan & & \\
& Baik & 25 & 49,0 \\
& Cukup & 15 & 29,4 \\
& Kurang & 11 & 21,6 \\
\hline
\end{tabular}

Berdasarkan tabel tingkat pengetahuan diatas dapat terlihat bahwa mayoritas yang paling banyak adalah responden dengan tingkat pengetahuan cukup yakni 29 orang $(56,9 \%)$ dan yang paling sedikit tingkat pengetahuan kurang sebanyak 8 orang $(15,7 \%)$.

Berdasarkan table sikap ibu diatas dapat terlihat bahwa mayoritas adalah sikap positif yakni sebanyak 29 orang responden $(56,9 \%)$ dan sikap negatif sebanyak 22 orang $(43,1 \%)$.

Berdasarkan table dukungan suami diatas dapat terlihat bahwa mayoritas adalah responden dengan suami yang mendukung yakni 30 orang $(58,8 \%)$ dan paling sedikit yang tidak mendukung yakni 30 orang $(58,8 \%)$.

Berdasarkan table peran petugas kesehatan diatas dapat terlihat bahwa mayoritas adalah baik yaitu 25 
Julina Br. Sembiring et al, Faktor-Faktor yang Berhubungan dengan Kesediaan Menjadi Akseptor KB Pasca Persalinan di RSUD Deli Serdang Lubuk Pakam Tahun 2019

orang (49\%) dan paling sedikit kurang yakni 11 orang $(21,6 \%)$.

\section{Analisis Univariat}

Faktor-faktor yang berhubungan dengan kesediaan menjadi akseptor KB Pasca Persalinan di Rumah Sakit Umum Daerah Deli Serdang Lubuk Pakam tahun 2018. Data yang dikumpulkan dianalisis dengan uji statistik uji chi-square dengan derajat kemaknaan $\alpha=0,05 \%$ akan dijelaskan sebagai berikut :

Tabel 2. Tabulasi Silang Faktor-Faktor Yang Berhubungan Dengan Kesediaan Mmenjadi Akseptor KB Pasca Persalinan di Rumah Sakit Umum Daerah Deli Serdang Lubuk Pakam Tahun 2019

\begin{tabular}{|c|c|c|c|c|c|c|c|}
\hline \multirow{2}{*}{ Tingkat Pengetahuan } & \multicolumn{2}{|c|}{ Bersedia } & \multicolumn{2}{|c|}{ Tidak Bersedia } & \multicolumn{2}{|c|}{ Total } & \multirow{2}{*}{ P-Value } \\
\hline & f & $\%$ & $\mathbf{f}$ & $\%$ & $\mathbf{F}$ & $\%$ & \\
\hline Baik & 14 & 27,5 & 0 & 0,0 & 14 & 27,5 & \\
\hline Cukup & 18 & 35,3 & 11 & 21,6 & 29 & 56,9 & 0,028 \\
\hline Kurang & 6 & 11,7 & 2 & 3,9 & 8 & 15,6 & \\
\hline \multirow{2}{*}{ Sikap Ibu } & \multicolumn{2}{|c|}{ Bersedia } & \multicolumn{2}{|c|}{ Tidak Bersedia } & \multicolumn{2}{|c|}{ Total } & \multirow{2}{*}{ P-Value } \\
\hline & $\mathbf{f}$ & $\%$ & $\mathbf{f}$ & $\%$ & $\mathbf{F}$ & $\%$ & \\
\hline Positif & 27 & 52,9 & 2 & 3,9 & 29 & 56,8 & \multirow{2}{*}{0.01} \\
\hline Negatif & 11 & 21,6 & 11 & 21,6 & 22 & 43,2 & \\
\hline \multirow{2}{*}{ Dukungan Suami } & \multicolumn{2}{|c|}{ Bersedia } & \multicolumn{2}{|c|}{ Tidak Bersedia } & \multicolumn{2}{|c|}{ Total } & \multirow{2}{*}{ P-Value } \\
\hline & $\mathrm{f}$ & $\%$ & $\mathrm{f}$ & $\%$ & $\mathrm{~F}$ & $\%$ & \\
\hline Mendukung & 29 & 56,9 & 1 & 2,0 & 30 & 58,9 & \multirow{2}{*}{0,000} \\
\hline Tidak Mendukung & 9 & 17,6 & 12 & 23,5 & 21 & 41,1 & \\
\hline \multirow{2}{*}{ Peran Petugas Kesehatan } & \multicolumn{2}{|c|}{ Bersedia } & \multicolumn{2}{|c|}{ Tidak Bersedia } & \multicolumn{2}{|c|}{ Total } & \multirow{2}{*}{ P-Value } \\
\hline & $\mathbf{f}$ & $\%$ & $\mathbf{f}$ & $\%$ & $\mathbf{F}$ & $\%$ & \\
\hline Baik & 25 & 49,0 & 0 & 0,0 & 25 & 49,0 & \\
\hline Cukup & 11 & 21,6 & 4 & 7,8 & 15 & 29,4 & 0,00 \\
\hline Kurang & 2 & 3,9 & 9 & 17,7 & 11 & 21,6 & \\
\hline
\end{tabular}

Berdasarkan tabel diatas diketahui bahwa dari 51 responden, dengan tingkat pengetahuan baik sebanyak 14 orang $(27,5 \%)$ bersedia menjadi akseptor KB pasca persalinan dan tidak ada yang tidak bersedia. Dari 51 responden dengan tingkat pengetahuan cukup, sebanyak 18 orang $(35,5 \%)$ bersedia menjadi akseptor KB pasca persalinan dan 11 orang $(21,6 \%)$ tidak bersedia. Dari 51 responden dengan tingkat pengetahuan kurang sebanyak 6 orang $(11,7 \%)$ bersedia menjadi akseptor KB pasca persalinan dan 2 orang $(3,9 \%)$ tidak bersedia. Hasil uji Chi Square diperoleh nilai $p$ value $=0,028$ maka $\mathrm{p}<$ 0,05 yang berarti terdapat hubungan yang significant antara tingkat pengetahuan ibu tentang alat kontrasepsi dengan kesediaan menjadi akseptor KB pasca persalinan.

Berdasarkan tabel diatas diketahui bahwa dari 51 reponden dengan sikap ibu positif sebanyak 27 orang $(52,9 \%)$ bersedia menjadi akseptor KB pasca persalinan dan 2 orang $(3,9 \%)$ tidak bersedia. Dari 51 responden dengan sikap ibu negative sebanyak 11 orang $(21,6 \%)$ bersedia menjadi akseptor KB pasca persalinan dan 11 orang $(21,6 \%)$ tidak bersedia. Hasil uji Chi Square diperoleh nilai $p$ value $=0,01$ maka $p<0,05$ yang berarti terdapat hubungan yang significant antara sikap ibu dengan kesediaan menjadi akseptor KB pasca persalinan.

Berdasarkan tabel diatas diketahui bahwa dari 51 responden dengan dukungan suami yang mendukung sebanyak 29 orang $(56,9 \%)$ bersedia menjadi akseptor KB pasca persalinan dan 1 orang (2\%) tidak bersedia. Dari 51 responden dengan dukungan suami yang tidak mendukung 9 orang $(17,6 \%)$ bersedia menjadi akseptor
KB pasca persalinan dan 12 orang $(23,5 \%)$ tidak bersedia. Hasil uji Chi Square diperoleh nilai significant $p$ value $=0,00$ maka $\mathrm{p}<0,05$ yang berarti terdapat hubungan yang significant antara dukungan suami dengan kesediaan menjadi akseptor KB pasca persalinan di RSUD Deli Serdang Lubuk Pakam.

Berdasarkan tabel diatas diketahui bahwa dari 51 responden dengan peran petugas kesehatan baik sebanyak 25 orang (49\%) bersedia menjadi akseptor KB pasca persalinan dan tidak ada responden $(0 \%)$ yang tidak bersedia. Dari 51 responden dengan peran petugas kesehatan cukup sebanyak 11 orang $(21,6 \%)$ bersedia menjadi akseptor KB pasca persalinan dan 4 orang $(29,4 \%)$ tidak bersedia. Dari 51 responden dengan peran petugas kesehatan kurang sebanyak 2 orang $(3,9 \%)$ bersedia menjadi akseptor KB pasca persalinan dan 9 orang $(17,7 \%)$ tidak bersedia. Hasil uji Chi Square diperoleh nilai $p$ value $=0,00<$ maka $p<0,05$ yang berarti terdapat hubungan yang significant antara peran petugas kesehatan dengan kesediaan menjadi akseptor KB pasca persalinan.

\section{Pembahasan}

Hubungan tingkat pengetahuan ibu tentang alat kontrasepsi dengan kesediaan menjadi akseptor KB pasca persalinan

Berdasarkan hasil penelitian diketahui bahwa dari 51 responden, dengan tingkat pengetahuan baik sebanyak 14 orang $(27,5 \%)$ bersedia menjadi akseptor KB pasca persalinan dan tidak ada yang tidak bersedia. 
Dari 51 responden dengan tingkat pengetahuan cukup, sebanyak 18 orang $(35,5 \%)$ bersedia menjadi akseptor KB pasca persalinan dan 11 orang $(21,6 \%)$ tidak bersedia. Dari 51 responden dengan tingkat pengetahuan kurang sebanyak 6 orang $(11,7 \%)$ bersedia menjadi akseptor KB pasca persalinan dan 2 orang $(3,9 \%)$ tidak bersedia. Hasil uji Chi Square diperoleh nilai $p$ value $=$ 0,028 maka $\mathrm{p}<0,05$ yang berarti terdapat hubungan yang significant antara tingkat pengetahuan ibu tentang alat kontrasepsi dengan kesediaan menjadi akseptor KB pasca persalinan.

Hasil penelitian ini sejalan dengan penelitian sebelumnya oleh Marlina L Simbolon, dengan hasil penelitian memperlihatkan pada variabel pengetahuan ibu diperoleh hasil bahwa ibu yang memiliki pengetahuan tidak baik lebih banyak proporsi yang tidak memakai AKDR yaitu sebanyak 34 orang $(64,2 \%)$ dibandingkan dengan yang memakai AKDR yaitu sebanyak 19 orang $(35,8 \%)$. Pada pada ibu yang memiliki pengetahuan baik lebih banyak proporsi ibu yang memakai AKDR yaitu sebanyak 31 orang $(66,0 \%)$ dibandingkan dengan yang tidak memakai AKDR yaitu sebanyak 16 orang $(34,0 \%)$. Berdasarkan hasil analisis statistik dengan uji Chi Square diperoleh nilai p-value $(0,003)<0,05$. Hal ini menunjukkan ada hubungan yang bermakna antara pengetahuan ibu dengan pemakaian AKDR di Puskesmas Tegal Sari III Medan tahun 2017.

Pengetahuan tentang metode kontrasepsi pasca persalinan harus didukung dengan pemahaman yang baik. Hal ini dapat menjadi bahan pertimbangan ibu untuk menentukan perlu tidaknya pengunaan alat kontrasepsi yang menjadi salah satu metode dalam kelurga berencana yaitu upaya menghindari kelahiran yang tidak diinginkan dengan mengatur interval diantara kelahiran dan mengontrol waktu kelahiran dalam hubungan dengan umur suami istri sehingga dapat menentukan jumlah keluarga (Vlorisa J, 2012).

Pengetahuan masyarakat tentang penggunaan alat kontrasepsi sangat diperlukan. Dalam penggunaan dan pemakaian alat kontrasepsi faktor-faktor tersebut perlu diketahui oleh pasangan calon pengguna alat kontrasepsi. Hal ini dikarenakan semua kontrasepsi mempunyai kegagalan dan juga dapat menimbulkan resiko tertentu pada pemakaiannya. Menurut Hartanto, adanya resiko yang potensial dalam bentuk ketidaknyamanan (inconvenience), misalnya senggama menjadi kurang/tidak menyenangkan, biaya yang tinggi dan lain-lain. Untuk menghindari resiko yang akan terjadi, sebaiknya pasangan calon pengguna alat kontrasepsi mengetahui terlebih dahulu berbagai macam alat atau metode kontrasepsi (Trisnawati L, n.d.).

Pengetahuan tentang keluarga berencana dipengaruhi banyak faktor. Kualitas dan kuantitas informasi merupakan salah satu faktor yang mempengaruhi tingkat pengetahuan. Demikian juga dengan tingkat pengetahuan ibu tentang keluarga berencana yang dipengaruhi juga oleh kualitas dan kuantitas informasi yang diperoleh ibu tersebut. Maka pelayanan Keluarga Berencana harus menjadi lebih berkualitas serta memperhatikan hak-hak dari pasien atau masyarakat dalam memilih metode kontrasepsi yang diinginkan (Saifuddin, 2003). Apabila informasi yang didapat seseorang mempunyai kualitas yang baik maka tingkat pengetahuan mereka akan bertambah karena informasi yang disampaikan benar, dengan cara penyampaian yang menarik sehingga orang akan mudah untuk memahami pesan yang disampaikan. Ibu yang memperoleh informasi tentang keluarga berencana yang berkualitas akan mempunyai pemahaman yang benar tentang alat kontrasepsi yang tepat digunakan setelah melahirkan. Seorang ibu dapat meningkatkan jumlah informasi yang banyak dengan membaca, menonton media elektronik, dan bertanya pada ahli.

Hasil penelitian diketahui bahwa mayoritas responden memiliki pengetahuan tentang alat-alat kontrasepsi yang baik. Hal ini dipengaruhi oleh faktor internal dan faktor eksternal. Faktor internal meliputi pendidikan dan umur. Mayoritas ibu yang berpengetahuan baik memiliki tingkat pendidikan yang tinggi dan berumur 20-35 tahun. Faktor eksternal yang mempengaruhi yakni faktor lingkungan dan peran petugas kesehatan. Berdasarkan wawancara diketahui bahwa mayoritas ibu sering mengikuti kegiatan posyandu di lingkungan sekitar tempat tinggalnya. Dalam kegiatan tersebut sering diberikan informasi tentang program keluarga berencana $(\mathrm{KB})$ dan alat-alat kontrasepsi oleh petugas kesehata.

Menurut asumsi peneliti, berdasarkan hasil penelitian terdapat hubungan yang significant antara tingkat pengetahuan ibu tentang alat kontrasepsi dengan kesediaan menjadi akseptor KB pasca persalinan dimana semakin tinggi tingkat pengetahuan seorang ibu tentang alat-alat kontrasepsi maka akan semakin meningkat minat untuk menjadi akseptor KB pasca persalinan.

\section{Hubungan sikap ibu dengan kesediaan menjadi akseptor KB pasca persalinan}

Berdasarkan hasil penelitian diketahui bahwa dari 51 reponden dengan sikap ibu positif sebanyak 27 orang $(52,9 \%)$ bersedia menjadi akseptor KB pasca persalinan dan 2 orang $(3,9 \%)$ tidak bersedia. Dari 51 responden dengan sikap ibu negative sebanyak 11 orang $(21,6 \%)$ bersedia menjadi akseptor KB pasca persalinan dan 11 orang $(21,6 \%)$ tidak bersedia. Hasil uji Chi Square diperoleh nilai $p$ value $=0,01$ maka $p<0,05$ yang berarti terdapat hubungan yang significant antara sikap ibu dengan kesediaan menjadi akseptor KB pasca persalinan.

Hasil penelitian ini sejalan dengan penelitian sebelumnya oleh Marlina L.Simbolon, dimana variabel sikap dapat dilihat bahwa pada ibu yang memiliki sikap tidak baik lebih banyak proporsi yang tidak memakai AKDR yaitu sebanyak 16 orang $(53,3 \%)$ dibandingkan 
dengan yang memakai AKDR yaitu sebanyak 14 orang $(46,7 \%)$. Pada pada ibu yang memiliki sikap baik lebih banyak proporsi ibu yang memakai AKDR yaitu sebanyak 36 orang $(51,4 \%)$ dibandingkan dengan yang tidak memakai AKDR yaitu sebanyak 34 orang $(48,6 \%)$. Dengan berdasarkan hasil analisis statistik dengan uji Chi Square diperoleh nilai $p$-value $(0,663)>0,05$. Hal ini menunjukkan tidak ada hubungan yang bermakna antara sikap ibu dengan pemakaian AKDR di Puskesmas Tegal Sari III Medan tahun 2017.

Sikap merupakan reaksi atau respon dari seseorang terhadap suatu stimulus atau objek, baik yang bersifat intern maupun ekstern sebagai manifestasinya tidak dapat langsung dilihat, tetapi hanya dapat ditafsirkan terlebih dahulu dari perilaku yang teretutup tersebut. Sikap tentang KB pasca persalinan adalah reaksi ibu pasca persalinan tentang penggunaan KB pasca persalinan sebagai salah satu alternatif penggunaan kontrasepsi.

Faktor yang mempengaruhi sikap : faktor intern (faktor yang melekat pada diri orang yang bersangkutan, misalnya pengalaman pribadi dan pengaruh emosional) dan faktor ekstern (faktor yang berasal dari luar diri orang misalnya pengaruh dari orang lain, pengaruh budaya, media ,masa, lembaga pendidikan dan agama (Vlorisa J, 2012)

Berdasarkan hasil penelitian diketahui bahwa dari 29 orang ibu yang bersikap positif 27 orang bersedia menjadi akseptor KB pasca persalinan dan 2 orang tidak bersedia. Menurut peneliti, pada ibu yang memiliki sikap positif namun tidak bersedia menjadi akseptor KB disebabkan oleh kurangnya dukungan dari suami, diman suami merencanakan untuk memperoleh anak lagi dengan alasan belum memiliki anak laki-laki. Sedangkan pada ibu yang bersikap negatif tetapi bersedia menjadi akseptor KB pasca persalinan karena adanya dukungan dari keluarga yang mengarahkan ibu untuk melakukan KB pasca persalinan.

Berdasarkan hasil penelitian dari 22 orang ibu yang bersikap negatif 11 orang bersedia menjadi akseptor KB pasca persalinan dan 11 orang tidak bersedia. Menurut peneliti, sikap ibu tentang penggunaan alat kontrasepsi pasca persalinan dipengaruhi oleh beberapa faktor, antara lain pengalaman pribadi, misalkan pada ibu multipara dan grandepara sebelumnya telah mengatur jarak kehamilan dengan menggunakan alat kontrasepsi. Faktor lain pengaruh orang yang dianggapnya penting, yakni suami yang memberikan dukungan terhadap niat ibu untuk menjadi akseptor KB pasca persalinan. Faktor lainnya yakni pengaruh media massa, gencarnya informasi tentang program $\mathrm{KB}$ di televise damn mediao sosial menambah pengetahuan ibu tentang $\mathrm{KB}$ sehingga meningkatkan minat dan sikap yag positif terhadap $\mathrm{KB}$ pasca persalinan.
Berdasarkan hasil wawancara dengan responden, sikap positif ibu juga dipengaruhi oleh lingkungan, baik lingkungan keluarga maupun masyarakat, yang akan menghasilkan adanya pengalaman tentang KB. Pengalaman-pengalaman tersebut dapat berupa pengertian $\mathrm{KB}$, efek samping, jenis $\mathrm{KB}$ dan sikap terhadap KB. Hal ini mempengaruhi sikap ibu tentang menjadi akseptor KB pasca persalinan.

Menurut asumsi peneliti maka terdapat hubungan yang significant antara sikap ibu dengan kesediaan menjadi akseptor KB pasca persalinan di RSUD Deli Serdang Lubuk Pakam. Pada ibu dengan sikap positif maka cenderung untuk menjadi akseptor KB persalinan, karena sikap positif ini mendorong ibu untuk bersedia menjadi akseptor KB pasca persalinan. Sedangkan pada ibu yang bersikap negatif maka cenderung untuk menolak menjadi akseptor KB pasca persalinan karena kurangnya keinginan untuk mengikuti program $\mathrm{KB}$ pasca persalinan.

\section{Hubungan dukungan suami dengan kesediaan menjadi akseptor KB pasca Persalinan}

Berdasarkan hasil penelitian diketahui bahwa dari 51 responden dengan dukungan suami yang mendukung sebanyak 29 orang $(56,9 \%)$ bersedia menjadi akseptor KB pasca persalinan dan 1 orang $(2 \%)$ tidak bersedia. Dari 51 responden dengan dukungan suami yang tidak mendukung 9 orang $(17,6 \%)$ bersedia menjadi akseptor KB pasca persalinan dan 12 orang $(23,5 \%)$ tidak bersedia. Hasil uji Chi Square diperoleh nilai significant $p$ value $=0,00$ maka $\mathrm{p}<0,05$ yang berarti terdapat hubungan yang significant antara dukungan suami dengan kesediaan menjadi akseptor KB pasca persalinan di RSUD Deli Serdang Lubuk Pakam.

Sejalan dengan hasil penelitian sebelumnya oleh Marlina L.Simbolon dengan hasil bahwa variabel dukungan suami dapat dilihat bahwa pada ibu yang memiliki dukungan tidak baik lebih banyak proporsi yang tidak memakai AKDR yaitu sebanyak 29 orang $(63,0 \%)$ dibandingkan dengan yang memakai AKDR yaitu sebanyak 17 orang $(37,0 \%)$. Pada pada ibu yang memiliki dukungan suami yang baik lebih banyak proporsi ibu yang memakai AKDR yaitu sebanyak 33 orang $(61,1 \%)$ dibandingkan dengan yang tidak memakai AKDR yaitu sebanyak 21 orang $(38,9 \%)$. Berdasarkan hasil analisis statistik dengan uji $C h i$ Square diperoleh nilai p-value $(0,016)<0,05$. Hal ini menunjukkan ada hubungan yang bermakna antara dukungan suami dengan pemakaian AKDR di Puskesmas Tegal Sari III Medan tahun 2017.

Dukungan suami merupakan salah satu variabel sosial budaya yang sangat berpengaruh terhadap pemakaian alat kontrasepsi bagi kaum wanita sebagai istri secara khusus dan didalam keluarga secara umum . Partisipasi pria secara tidak langsung salah satunya dengan cara mendukung istri dalam ber-KB. Jika 
Julina Br. Sembiring et al, Faktor-Faktor yang Berhubungan dengan Kesediaan Menjadi Akseptor KB Pasca Persalinan di RSUD Deli Serdang Lubuk Pakam Tahun 2019

disepakati istri yang ber-KB, maka peranan suami adalah memberikan dukungan dan kebebasan kepada istri untuk menggunakan kontrasepsi atau metode $\mathrm{KB}$ yang akan digunakan.

Hasil penelitian ini juga sesuai dengan penelitian yang dilakukan oleh (Susanto, 2016) mengatakan bahwa dalam pengambilan keputusan pemilihan kontrasepsi pasca persalinan, dukungan suami meliputi upaya memperoleh informasi, mengantarkan ke pelayanan kesehatan, dan membiayai pemasangan alat kontrasepsi. Semakin baik dukungan yang diberikan oleh suami maka dalam pengambilan keputusan sesuai dengan keinginan suami dan istri, sebaliknya jika dukungan suami kurang maka akan timbul ketidakpuasaan suami dalam pemilihan kontrasepsi.

Menurut Komang (2014) mengatakan bahwa suami merupakan pemimpin dan pelindung istri, maka kewajiban suami terhadap istrinya adalah mendidik, mengarahkan serta mengartikan istrinya kepada kebenaran, kemudian memberinya nafkah lahir batin, mempergauli serta menyantuni dengan baik. Maka untuk hal mendidik istri dalam pengambilan keputusan dan juga berkomunikasi untuk mendiskusikan kebijakan dalam merencanakan keluarga berencana. Sering terjadi dengan tidak adanya diskusi yang baik atau komunikasi yang baik sehingga dapat menjadi hambatan terhadap kelangsungan pemakaian alat kontrasepsi. Peran tenaga medis untuk lebih efektif dalam hal dukungan suami yaitu dibentuknya kelas ayah sangat membantu dalam hal menambah pengetahuan dari suami tersebut, sehingga bisa mengayomi istri dalam hal pengambilan keputusan.

Hubungan suami mempunyai suatu tanggung jawab yang penuh dalam keluarga dan suami mempunyai peranan penting ketika suami sangat dituntut bukan hanya sebagai pencari nafkah akan tetapi suami sebagai motivator dalam berbagai kebijakan yang akan diputuskan termasuk merencanakan keluarga berencana. Hal ini tidak terlepas dari komunikasi atau diskusi antara kedua belah pihak (suami dan istri) terlebih dahulu. Oleh karena itu dengan tidak adanya diskusi antara suami dan istri dapat menjadi hambatan terhadap kelangsungan pemakaian alat kontrasepsi.

Berdasarkan hasil penelitian diketahui bahwa dari 30 orang ibu yang mempunyai suami yang mendukung 29 orang bersedia menjadi akseptor KB pasca persalinan dan 1 orang tidak bersedia. Diketahui adanya ibu dengan suami yang mendukung namun tidak bersedia menjadi akseptor KB pasca persalinan adalah karena kurangnya pengetahuan ibu terhadap alat-alat kontrasepsi. Hasil wawancara pada ibu ini diketahui ibu begitu cemas dengan penggunaan alat-alat kontrasepsi dan banyak mendengar hal-hal negatif dari pemasangan alat-alat kontrasepsi.

Berdasarkan hasil penelitian ditemukan ibu yang suaminya tidak mendukung namun bersedia menjadi akseptor KB pasca persalinan. Pada ressponden ini adalah adanya kesadaran dari ibu mengenai faktor ekonomi keluarga. Ibu merencanakan untuk bekerja membantu suami segera setelah masa nifas bearkhir. Jadi walaupun suaminya kurang memberikan dukungan, ibu tetap bersedia untuk menjadi akseptor $\mathrm{KB}$ pasca persalinan.

Menurut asumsi peneliti maka berdasarkan hasil penelitian, terdapat hubungan yang significant antara dukungan suami dengan kesediaan menjadi akseptor KB pasca persalinan di RSUD Deli Serdang Lubuk Pakam, yang berarti pada ibu yang mendapatkan dukungan suami maka akan cenderung untuk menjadi akseptor KB $\mathrm{KB}$ pasca persalinan, sedangkan jika ibu tidak mendapatkan dukungan suami, maka cenderung untuk tidak bersedia menjadi akseptor KB pasca persalinan.

\section{Hubungan peran petugas kesehatan dengan kesediaan menjadi akseptor KB pasca persalinan}

Berdasarkan hasil penelitian diketahui bahwa dari 51 responden dengan peran petugas kesehatan baik sebanyak 25 orang (49\%) bersedia menjadi akseptor KB pasca persalinan dan tidak ada responden $(0 \%)$ yang tidak bersedia. Dari 51 responden dengan peran petugas kesehatan cukup sebanyak 11 orang $(21,6 \%)$ bersedia menjadi akseptor KB pasca persalinan dan 4 orang $(29,4 \%)$ tidak bersedia. Dari 51 responden dengan peran petugas kesehatan kurang sebanyak 2 orang $(3,9 \%)$ bersedia menjadi akseptor KB pasca persalinan dan 9 orang $(17,7 \%)$ tidak bersedia. Hasil uji Chi Square diperoleh nilai $p$ value $=0,00<$ maka $\mathrm{p}<0,05$ yang berarti terdapat hubungan yang significant antara peran petugas kesehatan dengan kesediaan menjadi akseptor $\mathrm{KB}$ pasca persalinan.

Hasil penelitian ini sejalan dengan penelitian sebelumnya oleh Marlina L.Simbolon pada variabel peran tenaga kesehatan dapat dilihat bahwa ibu yang menilai peran tenaga kesehatannya tidak baik lebih banyak proporsi yang tidak memakai AKDR yaitu sebanyak 37 orang $(63,8 \%)$ dibandingkan dengan yang memakai AKDR yaitu sebanyak 21 orang $(36,2 \%)$. Pada pada ibu yang menilai peran tenaga kesehatannya baik lebih banyak proporsi ibu yang memakai AKDR yaitu sebanyak 29 orang $(69,0 \%)$ dibandingkan dengan yang tidak memakai AKDR yaitu sebanyak 13 orang $(31,0 \%)$. Berdasarkan hasil analisis statistik dengan uji Chi Square diperoleh nilai p-value $(0,001)<0,05$. Hal ini menunjukkan ada hubungan yang bermakna antara peran tenaga kesehatan dengan pemakaian AKDR di Puskesmas Tegal Sari III Medan tahun 2017.

Peran petugas kesehatan dalam KB juga berhubungan erat dengan sikap dan dukungan suami. Sikap dan dukungan yang dapat diberikan dalam penggunaan alat kontrasepsi, terlihat dari keikutsertaan suami mengantarkan isteri ke pelayanan kesehatan untuk bersama-sama berkonsultasi dan menentukan jenis alat 
Julina Br. Sembiring et al, Faktor-Faktor yang Berhubungan dengan Kesediaan Menjadi Akseptor KB Pasca Persalinan di RSUD Deli Serdang Lubuk Pakam Tahun 2019

kontrasepsi yang akan digunakan serta memilih kontrasepsi yang cocok merupakan hal penting yang harus didiskusikan dan diputuskan bersama.

Petugas kesehatan mempunyai peran yang sangat penting dalam memberikan pelayanan kepada masyarakat khususnya di Puskesmas, peran petugas ini mencakup upaya promotif, preventif, kuratif dan rehabilitatif. Peran petugas kesehatan bagi ibu hamil dan bersalin adalah maningkatkan pengetahuan, perubahan perilaku, meningkatkan kepatuhan sehingga akan meningkatkan kualitas hidup.

Tenaga kesehatan seperti perawat, bidan dan dokter merupakan sumber informasi yang tampak dan kompeten bagi klien yang ingin meningkatkan kondisi fisik dan psikologisnya. Tenaga kesehatan memberikan informasi dan keterampilan dan dapat mengubah perilaku masyarakat menjadi lebih sehat.

Promosi kesehatan bukan hanya kegiatan penyadaran masyarakat atau pemberian dan peningkatan pengetahuan masyarakat tentang kesehatan tetapi juga merupakan upaya-upaya dalam memfasilitasi perubahan perilaku kesehatan yang diinginkan. Informasi yang diberikan bukan hanya melakukan perubahan perilaku saja melainkan juga upaya perubahan lingkungan, sosial budaya, politik dan ekonomi (Setiawati, 2008).

Berdasarkan hasil penelitian ditemukan ibu dengan peran petugas kesehatan yang baik mayoritas bersedia menjadi akseptor KB pasca persalinan. Ibu yang mendapatkan KIE dari petugas kesehatan yang baik, akan menjadi akseptor KB pasca persalinan. Kebutuhan informasi dan konseling tentang kehidupan seksual dan kontrasepsi merupakan salah satu pertanyaan yang banyak diajukan pada pasca persalinan. Ada kemungkinan besar bahwa sebagian besar ibu menghindari hubungan seksual selama hamil sampai dengan sesudah persalinan.

Berdasarkan hasil penelitian juga ditemukan ibu dengan peran petugas kesehatan yang baik namun tidak bersedia menjadi akseptor KB pasca persalinan adalah karena kurangnya dukungan dari suami pada responden ini, sebagian besar mengatakan suami jarang mau mengantarkan istrinya untuk ke fasilitas kesehatan, jadi suami jarang mendapatkan informasi tentang penggunaan alat-alat kontrasepsi dan suami yang mesih menginginkan anak laki-laki.

Menurut asumsi peneliti, maka berdasarkan hasil penelitian maka terdapat hubungan yang significant antara peran petugas kesehatan dengan kesediaan menjadi akseptor $\mathrm{KB}$ pasca persalinan dengan asumsi bahwa semakin baik peran petugas kesehatan maka semakin besar minat ibu untuk menjadi akseptor $\mathrm{KB}$ pasca persalinan.

\section{SIMPULAN}

Berdasarkan umur terdapat hubungan dengan kesediaan menjadi akseptor $\mathrm{KB}$ pasca persalinan di
RSUD Deli Serdang Lubuk Pakam dengan hasil Uji Chi Square diperoleh nilai $p$ value $0,000<0,05$.

Berdasarkan pendidikan tidak terdapat hubungan dengan kesediaan menjadi akseptor KB pasca persalinan di RSUD Deli Serdang Lubuk Pakam dengan hasil Uji Chi Square diperoleh nilai $p$ value 0,327 >0,05.

Berdasarkan paritas terdapat hubungan dengan kesediaan menjadi akseptor KB pasca persalinan di RSUD Deli Serdang Lubuk Pakam dengan hasil Uji Chi Square diperoleh nilai $p$ value $0,04<0,05$.

Berdasarkan pengetahuan tentang alat kontrasepsi terdapat hubungan dengan kesediaan menjadi akseptor KB pasca persalinan di RSUD Deli Serdang Lubuk Pakam dengan hasil Uji Chi Square diperoleh nilai $p$ value $0,028<0,05$.

Berdasarkan sikap ibu terdapat hubungan dengan kesediaan menjadi akseptor KB pasca persalinan di RSUD Deli Serdang Lubuk Pakam dengan hasil Uji Chi Square diperoleh nilai $p$ value $0,01<0,05$.

Berdasarkan dukungan suami terdapat hubungan dengan kesediaan menjadi akseptor KB pasca persalinan di RSUD Deli Serdang Lubuk Pakam dengan hasil Uji Chi Square diperoleh nilai $p$ value $0,00<0,05$.

Berdasarkan peran petugas kesehatan terdapat hubungan dengan kesediaan menjadi akseptor KB pasca persalinan di RSUD Deli Serdang Lubuk Pakam dengan hasil Uji Chi Square diperoleh nilai $p$ value $0,00<0,05$.

\section{DAFTAR PUSTAKA}

Badan Kependudukan dan Keluarga Berencana Nasional. (2013). Survei Demografi danKesehatan Indonesia 2013.

Bappenas. (2013). Arah Pembangunan Kependudukan dan KeluargaBerencana dalam RKP 2012 dan Rancangan RKP 2013. BadanPerencana Pembangunan Nasional.

Berlinda Wakerkwa. (n.d.). Faktor-faktor yang berhubungan dengan pengunaan kontrasepsi Implant di wilayah kerja Puskesmas Teladan Kecamatan Medan Kota tahun 2017.

Kementerian Kesehatan RI. (2017). Program Kesehatan Reproduksi danPelayanan Integratif di Tingkat Pelayanan Dasar. Jakarta: Kemenkes RI.

RSUD Deli Serdang. (n.d.). Profil RSUD Deli Serdang Lubuk Pakam tahun 2017. Lubuk Pakam: RSUD Deli Serdang.

Tita.H.M. (2014). Hubungan Antara Dukungan Suami dan Pengetahuan Ibu dengan Pemilihan Alat Kontrasepsi Intra Uterine Device (IUD) di Puskesmas Polokarto Kabupaten Sukoharjo. Muhammadiyah Surakarta.

Trisnawati L, dkk. (n.d.). Hubungan antara pengetahuan tentang $K B$ MKJP dan sikap ibu peserta Kampersal pasca persalinan dengan penggunaan KB MKJP di Puskesmas Kartasura.

Vlorisa J. (2012). Penggunaan kontrasepsi pada wanita 
Julina Br. Sembiring et al, Faktor-Faktor yang Berhubungan dengan Kesediaan Menjadi Akseptor KB Pasca Persalinan di RSUD Deli Serdang Lubuk Pakam Tahun 2019

pasca melahirkan dan pasca keguguran.

WHO. (2016). Family Planning a Global Handbook for Providers (Evidence-b). United States Agency for International Development Bureau for GlobalHealth Office of Population and Reproductive Health. 